\title{
超音波を用いた下水管更生用 GFRP 成形板の硬化不良検出
}

\author{
和田 明浩*1, 山崎 友裕*2, 北川 英二*3, 伊 藤 博*3 \\ (2015 年 4 月 29 日受付)
}

\author{
Ultrasonic Detection of Uncured Region in GFRP Laminates for \\ Rehabilitation of Sewerage Pipes
}

\begin{abstract}
Akihiro WadA, ${ }^{* 1}$ Tomohiro Yamasaki, ${ }^{* 2}$ Eiji KiTAgawA ${ }^{* 3}$ and Hiroshi Ito*3
\end{abstract}
(Received April 29, 2015)

\begin{abstract}
A new technique using Lamb wave is proposed to detect uncured region in GFRP laminates nondestructively. Polymer based composites play an increasingly important role in the field of civil engineering in recent years. For example, laminated sheets consisting of thermoplastic layer, organic fabric sheets and SMC (sheet molding compound) are used to rehabilitate aged sewerage pipes. The cylindrical laminate is inserted in the pipe, and is inflated and cured by steam blowing to create close-fit pipe. This CIPP (cured in place pipe) is one of several trenchless rehabilitation methods to repair aged pipes. In this study, ultrasonic Lamb wave is applied to the detection of uncured region in a laminated composite plate. Oblique incidence method in which ultrasonic waves are launched by the transducer inclined at a selected angle is applied to excite specific mode of Lamb waves in the laminate. Wheel type probes are used to improve inspection efficiency. Beside wave attenuation, AU parameters which are derived from power spectrum of a broadband signal are introduced. It is found that application of AU parameters leads to the improvement of the detectability of uncured region.
\end{abstract}

Key words: Composite material, Laminated construction, Nondestructive inspection, Ultrasonic inspection, Lamb wave, Spectrum analysis

\section{1. 緒}

\section{言}

我が国では近年，社会インフラとして整備された土木 構造物の老朽化が問題視されており，高い比強度と比剛 性を有し現場施工性にも優れた繊維強化プラスチック (FRP) による補修工事が行われている。我及の生活を支 える重要なインフラの 1 つである下水道に扔いても管路 の老朽化が顕在化しており，下水管の破損に伴う道路陥 没事故も多発している．例えば，神戸市の下水道は昭和
26 年の整備開始以来約 60 年が経過し, 污水管きょの敷 設延長は平成 22 年度末で $4036 \mathrm{~km}$ とほぼ全域で整備が 概成した ${ }^{11}$. しかし，管年齢 30 年を超過した管きょが全 体の約 $50 \%$ を占めており, 管きょの老朽化に起因した漏 水, 道路陥没などの事故の増加が懸念される.このため, 適切な管理による下水道の定期的な検查, 補修が重要と なる.補修方法の 1 つとして,古くなった下水管の中に未 硬化の筒状 FRP シートを挿入し，蒸気により管内で膨 らませて内面に圧着するとともに加熱硬化させて下水管

*1 神戸市立工業高等専門学校機械工学科 教授 (651-2194 兵庫県神戸市西区学園東町 8-3)

Professor, Department of Mechanical Engineering, Kobe City College of Technology, 8-3, Gakuenhigashimachi, Nishi-ku, Kobe 651-2194, Japan

*2 大阪市立大学大学院工学研究科 教授 (558-8585 大阪府大阪市住吉区杉本 3-3-138)

Professor, Department of Mechanical Engineering, Osaka City University, 3-3-138, Sugimoto, Sumiyoshi-ku, Osaka 558-8585, Japan

*3 芦森工業株式会社機能製品事業本部（566-0001 大阪府摂津市千里丘 7-11-61）

High Performance Product Business Division, Ashimori Industry Co.,LTD., 7-11-61, Senrioka, Settsu, Osaka 566-0001, Japan 
内面に FRP パイプを形成する管更生工法 (CIPP) があ る.この工法では施工後に TV カメラ調查が実施されて いるが, FRP パイプの硬化状態を把握できないため, 地 下水などの影響による部分的な温度上昇不足のために生 じる硬化不良部を見逃す可能性がある。硬化不良部の存 在は強度不足や漏孔の原因となるため, 下水管内に形成 した FRP パイプの硬化状態を非破壊検査する手法が望 まれている.

樹脂成形品の硬化度評価の取り組みとしては誘電率測 定 $^{21}$, 光ファイバによるひずみ測定 ${ }^{3)}$ などが研究されてい るが，これらはセンサの材料表面への貼り付けや材料内 部への埋め込みが必要なため測定位置の走査が困難であ り，検査コストが高いという問題もある。超音波検查で は音速測定 ${ }^{4)}$ や金型界面反射波の測定 ${ }^{5}$ などが研究され ており原理的に測定位置の走査が可能であるが，板厚方 向の超音波計測に基づく手法では一度に検查できる領域 が狭く検查効率が悪い. 板厚方向検查以外の手法として 板面内を伝播するラム波（板波）を利用した検查方法が あり, Guo ら ${ }^{6)}$, Tan ら ${ }^{7)}$ をじめ多くの研究者により $\mathrm{FRP}$ 積層板の損傷検查に適用した例は報告されている が，硬化不良部検出への適用事例は見当たらない。そこ で本研究では, CIPP 法で用いられるものと同じ材質の GFRP 積層平板を対象にラム波を用いた硬化不良部検 出の有効性について検討した。特に，下水道更生管の上 うな大型構造物の連続検查に適した夕イヤ探触子を用い てラム波の送受信を試みた。材料評価パラメータとして 振幅減衰率に加えて広带域信号の分析に用いられる $\mathrm{AU}$ パラメータ (acousto-ultrasonic parameter) を導入し, 検查精度の改善を試みた。

\section{2. タイヤ探触子を用いた超音波測定}

\section{1 ラム波測定法}

超音波検査では欠陥などの内部反射源からの反射波を 検出する手法が一般的であるが，硬化不良部検出におい ては硬化部と硬化不良部の境界が明確でなく, 領域境界 からの反射波の検出は望めない.このため検查領域を透 過した超音波の変化を評価する必要がある。また, 超音 波を板厚方向に入射した場合は一度に検查できる範囲が 探触子直下部に限定されるため広域の検查には時間を要 するそそこで本研究では, 試料面内を伝播するラム波を 計測対象とした. FRP 積層板は微視的には非均質材料で あるが，検査に用いるラム波の波長が材料の微視構造に 比べて十分に大きければ均質材の波動伝播理論が適用で きる。ラム波は複数の伝播モードを有することが知られ

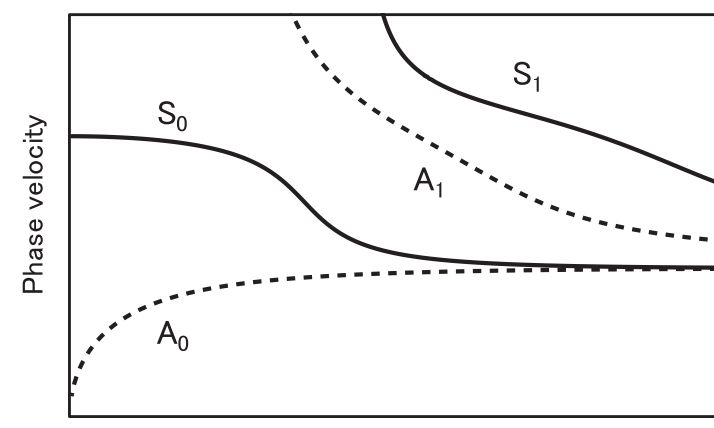

(Frequency) $\times($ Plate thickness)

Fig. 1 Schematic illustration of dispersion curves of Lamb waves.

\section{$\mathrm{S}_{0}$ mode}

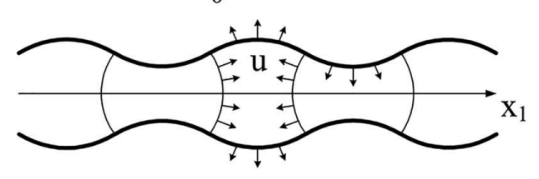

$\mathrm{A}_{0}$ mode

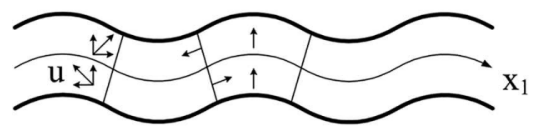

Fig. 2 Deformation of $\mathrm{S}_{0}$ and $\mathrm{A}_{0}$ Lamb modes.

ており，Fig. 1 に模式的に示すように各モードには特有 の速度分散性がある。モードは対称モード (S モード) と 反対称モード (Aモード) に分類され，それぞれ0次 モードから高次モードが存在するが, 周波数と板厚の積 が小さい領域では Fig. 2 に示す 2 つ 0 次モードのみ が存在できる ${ }^{8}$. $\mathrm{S}_{0}$ モードは板中心面に対して対称な変 形様式を示し, $\mathrm{A}_{0}$ モードは反対称な変形様式となる. $\mathrm{S}_{0}$ モードは低周波数域において分散性が弱いため, 伝播に 伴う波形の崩れが少なく検查に適していると考元られ る. 本研究では, 0 次モードが主として励起される低い周 波数帯の波を用い, $\mathrm{S}_{0}$ モードが $\mathrm{A}_{0}$ モードに比べて伝播 速度が速いことを利用して, $\mathrm{S}_{0}$ モードが支配的な受信波 の先頭領域を解析対象とした。

ラム波を効率よく送受信する方法として屈折を利用し た斜角入射法がある. 斜角入射法では Fig. 3 亿示すよう に試料表面に対して送受信探触子を対称に設置し, 送信 探触子から斜角入射された縱波が屈折して板面内をラム 波として伝播する際に水中に漏洩する緃波を受信探触子 で検出する。このとき，検查領域は送受信探触子に挟ま 


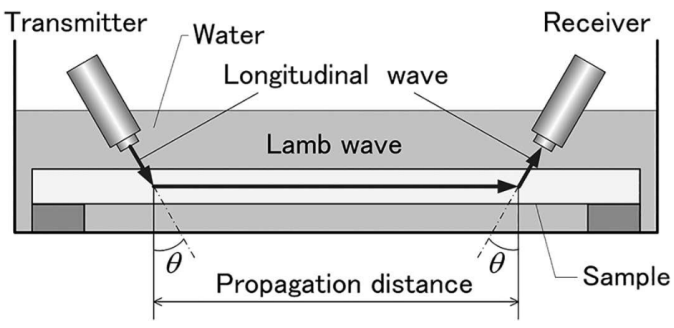

Fig. 3 Schematic illustration of ultrasonic oblique incidence.

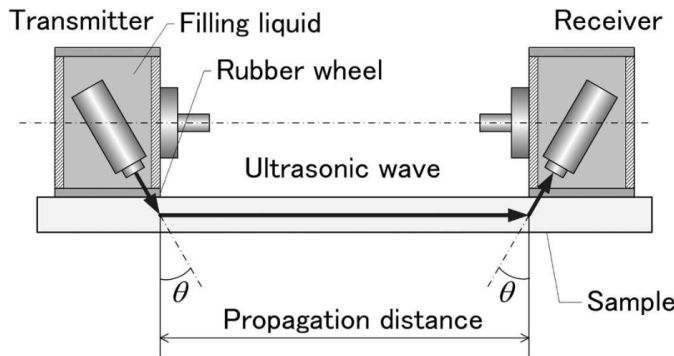

Fig. 4 Schematic illustration of ultrasonic testing with wheel type probes.

れた領域となる。しかし，この方法では超音波の伝達効 率を高めるために探触子と試料の間を水で満たす必要が あり，検査対象物を水没させなければならないため下水 管などの実構造物の検査には適さない. そこで, Fig. 4 の ようなタイヤ探触子を用いた測定方法が提案されてい る ${ }^{9)}$. 夕イヤ探触子の夕イヤ内部には縦波用探触子が斜 角で配置されており，探触子から発生した超音波は充填 液およびゴムタイヤを介して試料表面から内部に入射さ れる.夕イヤが試料表面上を転がることにより連続的な 測定が可能となる．超音波の減衰率は試料の材料特性に 依存しているため，受信波振幅の変化が未硬化領域検出 の指標となり得るが，受信波振幅は超音波の入射効率に 依存するため検査結果に摇らぎが生じる可能性がある. そこで本研究では，受信波の振幅減衰率に基づく評価に 加えて周波数領域での変化を評価するために $\mathrm{AU}$ パラ メータを用いた。

\section{$2.2 \mathrm{AU}$ パラメータ}

$\mathrm{AU}$ パラメータは被検査材を伝播する広帯域超音波の スペクトル線図から算出されるパラメータであり，受信 波が持つ周波数特性の定量的な評価に利用されてい る ${ }^{10 \sim 12)}$. 著者らはこれまで, 複合材料の内部損傷検出に 対する AUパラメータの有効性について検討しており, $\mathrm{AU}$ パラメータが超音波の送受信効率の影響を受けにく いことを明らかにしている(13). 本研究では, $\mathrm{AU}$ パラメー
夕が硬化不良部検出に対してどの程度の感度を有するか を実験的に検証する。

$\mathrm{AU}$ パラメータは次式で表わされるスペクトルモーメ ントより算出される。

$$
M_{n}=\int_{0}^{f_{m}} W(f) f^{n} d f
$$

ここで, $W(f)$ はスペクトル密度関数, $f$ は周波数, $f_{m}$ は ナイキスト周波数であり， $n$ はスペクトルモーメントの 次数を表わす整数である。例えば $n=0$ の場合は次式と なる。

$$
M_{0}=\int_{0}^{f_{m}} W(f) d f
$$

式(2)はスペクトル線図の面積を表わしており,波の持つ エネルギに相当する。これまでに複数の AUパラメータ が提案されているが, 本研究では Kiernanらにより FRP 積層板への適用実績がある以下の 4 つのパラメー 夕10,11) を利用する。

$$
\begin{aligned}
& A 1=M_{0}, \quad A 2=\frac{M_{1}}{M_{0}} \\
& A 3=\left(\frac{M_{2}}{M_{0}}\right)^{0.5}, \quad A 4=\left(\frac{M_{4}}{M_{2}}\right)^{0.5}
\end{aligned}
$$

$A 1$ パラメータはスペクトルの0次モーメントと等し く, $A 2$ パラメータはスペクトル線図の罒心に相当し, 波 の中心周波数を表わしている.A2 パラメータが大きい ときは，波のエネルギの多くがより高い周波数領域で輸 送されていることを意味する. $A 3$ および $A 4$ パラメー夕 は波形の統計処理に基づいて算出されるパラメータであ り，A3 は時間波形が 0 レベルを通過する頻度（周波数） に対応し，A4 は時間波形に含まれる最高周波数を表わ している ${ }^{14)} . A 4 / A 3$ は比較的低い周波数を持つ主要波の 中に高周波数成分の波がどの程度含まれているか，すな わちスペクトル線図の“ねじれ”を表す指標となる。

\section{3.ラム波を用いた硬化不良部の検出}

\section{1 供 試 材}

本研究では，下水道管の更生に使用されているものと 同じ材料構成で成形した平板状試料を評価対象とした。 実際の管更生では既設管の内側に圧着するように更生管 を成形するが，既設管と更生管は接着しておらず，両者 の間にはある程度の空気層が存在するため，既設管への 波の漏洩は少ないと考えられる。また，更生管は曲率を 有しているが, 直径と板厚の比が 50 程度と大きいため, 平板のラム波分散曲線を近似的に適用できる ${ }^{15)}$.

試料は Fig. 5 に示すように更生管の内側になる層か 


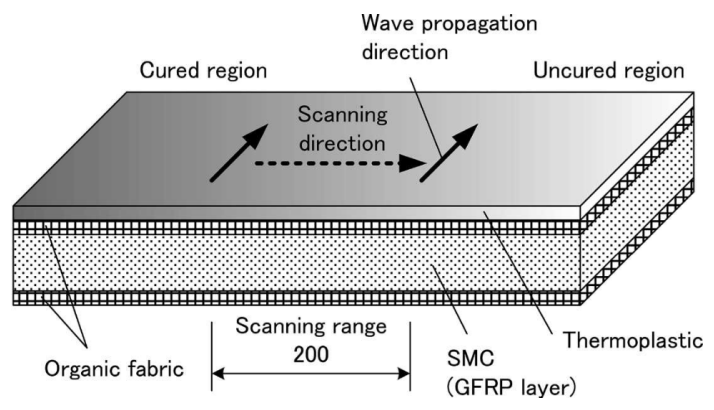

Fig. 5 Configuration of laminated composite plate.

ら順に,オレフィン系熱可塑性樹脂／PET 繊維製織物／ $\mathrm{SMC} / \mathrm{PET}$ 繊維製織物の 4 層構造である. SMC 層の主 成分は不飽和ポリエステル樹脂とガラス短繊維であり, 成形時に昇温することで樹脂を硬化させ GFRP 層を形 成する.試料サイズは $300 \mathrm{~mm} \times 600 \mathrm{~mm}$ であり，成形の 際に右半領域の金型温度を十分に上昇させないことによ り意図的に硬化不良部を作製した。成形後の試料は板厚 が約 $5 \mathrm{~mm}$ で硬化度が一方向に傾斜的に変化したものと なった.この試料は板厚方向に非対称な積層材であり, 均質材を対象としたラム波伝播理論は㛜密には適用でき ない。 また，全板厚に占める表面材の割合は $30 \%$ 程度で あり無視できないが, 本研究では均質材に対するラム波 計測手法を用いて硬化不良の検出がどの程度可能か検討 した.

\section{2 ラム波送受信条件の検討}

2.1 節で述べた測定法においては, 探触子の試料表面に 対する傾斜角がラム波入射効率に大きな影響を持つ。 そ こで，前節で示した積層板に対してラム波送受信に適し た探触子傾斜角を実測より求めた。ここでは夕イヤ探触 子のかわりに中心周波数 $1 \mathrm{MHz}$ の水浸探触子を用い, タイヤ探触子の送受信感度が比較的高かった搬送波周波 数 $160 \mathrm{kHz} ， 320 \mathrm{kHz}$ の 2 種類のバースト波（振幅 100 $\mathrm{Vp}-\mathrm{p}, 5$ 周期分) で測定を行った. 測定は局所水浸法で行 い, Fig. 5 の熱可塑性樹脂層側から超音波を入射しラム 波伝播距離は $100 \mathrm{~mm}$ で固定した。Fig. 6 に示した探触 子傾斜角と受信波振幅の関係をみると, いずれの入力周 波数においても受信波振幅のピークが確認でき， 160 $\mathrm{kHz}$ では $22^{\circ}, 320 \mathrm{kHz}$ では $24 \sim 26^{\circ}$ が最適角となった。 屈折の法則（スネルの法則）より，材料中の超音波伝播 速度が小さいほど最適入射角は大きくなる.よって, 160 $\mathrm{kHz}$ に比べて $320 \mathrm{kHz}$ は超音波伝播速度が小さいと考 えられ, Fig. 1 において $\mathrm{S}_{0}$ モードが周波数の増加に伴い

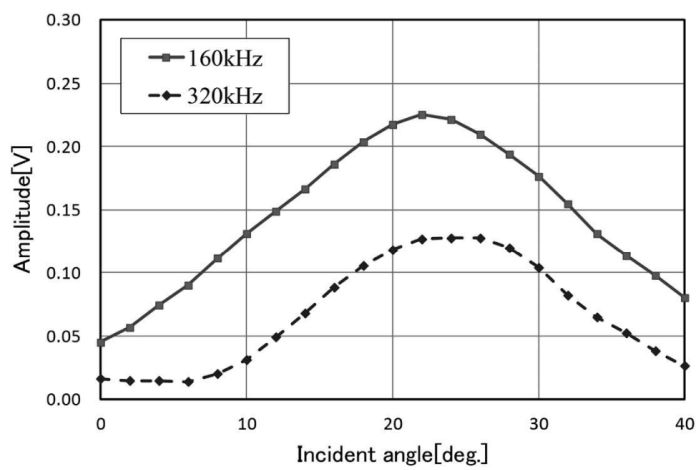

Fig. 6 Variation in wave intensity with inclined angle of the transducer.

位相速度が低下する傾向にあることと対応している。し かし，周波数による最適角の相違はわずかであり，位相 速度換算では $10 \%$ 程度の差となるため, Fig. 1 に示した 分散曲線において $\mathrm{S}_{0}$ モードと $\mathrm{A}_{0}$ モードの位相速度が 接近する領域まで至っていないと考えられる。この領域 では, $\mathrm{A}_{0}$ モードの群速度も相対的に遅いことから, 波の 先頭付近を解析することで $\mathrm{S}_{0}$ モードのみの解析が可能 となる。

斜角入射法では試料を水没あるいは局所水浸状態にす る必要があるが, 下水道更生管のような大型構造物に対 して水没試験は適用できず，一般的な局所水深法も測定 位置の走査が困難なため適さない. 一方, 夕イヤ探触子 では Fig. 4 のようにタイヤを試料表面で転がしながら 検査することで局所水浸状態を維持しながら広範囲を短 時間で検査可能である。しかし, 探触子を夕イヤ内部に 収める必要があるためその傾斜角には制約がある。そこ で以下では，市販の夕イヤ探触子(探触子傾斜角 $10^{\circ}$ ) を 使用してラム波の送受信が可能か検討した. 入力信号は 事前検討で比較的感度の高かった搬送波周波数 $320 \mathrm{kHz}$ で振幅 $100 \mathrm{Vp-p,} 5$ 周期分のバースト波を用い, Fig. 5 で 示した試料の完全硬化部に対し伝播距離 100〜140 mm の範囲で測定した. なお, 夕イヤ探触子と試料の接触面 には接触媒質としてソニコートを塗布して信号の送受信 効率を高めた。

Fig. 7 に受信波形，Fig. 8 にそのウェーブレット変換 結果を示す.マザーウェーブレットとしては Gabor 関数 を用いた。受信波形を観察すると 2 種類の波が干渉して いるようにみえ, 伝播距離が大きくなるにつれて各波の 時間軸方向の相対位置関係が変化している様子がうかが える.ウェーブレット変換結果をみると, $320 \mathrm{kHz}$ 付近 と $160 \mathrm{kHz}$ 付近にそれぞれピークがみられる. $320 \mathrm{kHz}$ 

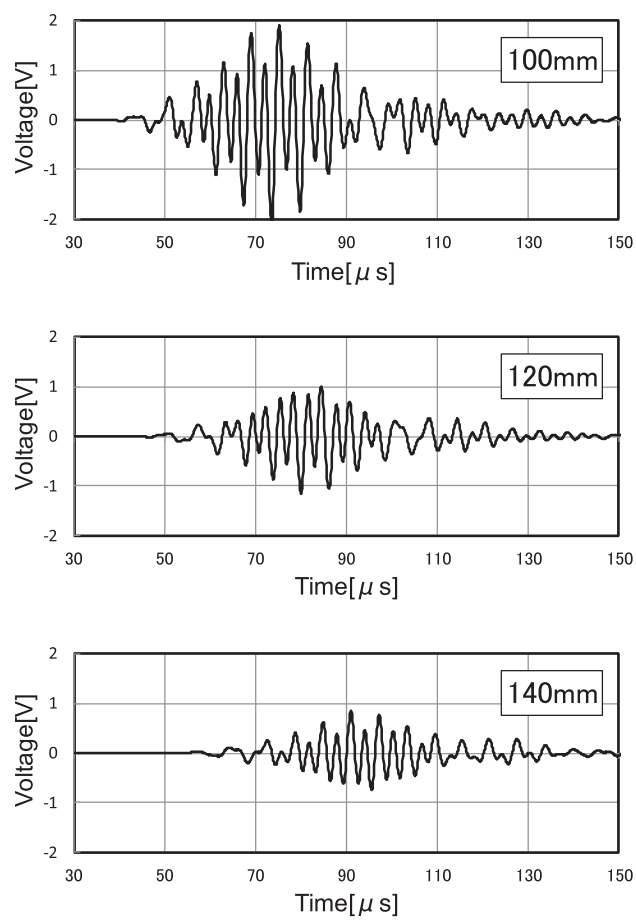

Fig. 7 Example of detected waveforms. Mixed mode waves are observed.

付近の波はバースト波による強制振動成分であり，160 $\mathrm{kHz}$ 付近の波は夕イヤ探触子が持つ低次の共振周波数 成分である。ここで各成分波の到達時刻を比較すると， $320 \mathrm{kHz}$ 付近の成分よりも $160 \mathrm{kHz}$ 付近の成分の到達 時刻が早く，伝播距離が大きくなるにつれてその差が大 きくなる傾向がみられる. $320 \mathrm{kHz}$ 以下の周波数帯であ れば， $\mathrm{A}_{0}$ モードの群速度が相対的に遅いため波の先頭 には現れないこと, および $\mathrm{S}_{0}$ モードは周波数が低いと き群速度が速くなる傾向にあり, $\mathrm{A}_{0}$ モードは逆の傾向 を示すことを考慮すると, 上記の 2 つのピークは異なる 周波数帯の $\mathrm{S}_{0}$ モードが干渉した結果と解釈できる。ま た， $160 \mathrm{kHz}$ 付近の波は伝播距離が大きくなるに伴い 2 つに分離する傾向がみられ，時間軸上の後方に位置する 波は伝播距離の増加に伴い波束の幅が広がる分散性を示 しており， $A_{0}$ モードの特徴と一致している．以上の結 果より，ラム波送受信の最適角からずれたタイヤ探触子 を用いても $\mathrm{S}_{0}$ モードラム波の送受信が可能であり，第 1 ピーク波付近を抜き出せば $\mathrm{S}_{0}$ モード主体の解析が可 能と考えられる。

\section{3 受信波振幅による評価}

3.1 節で示した硬化度が傾斜的に変化する GFRP 積層
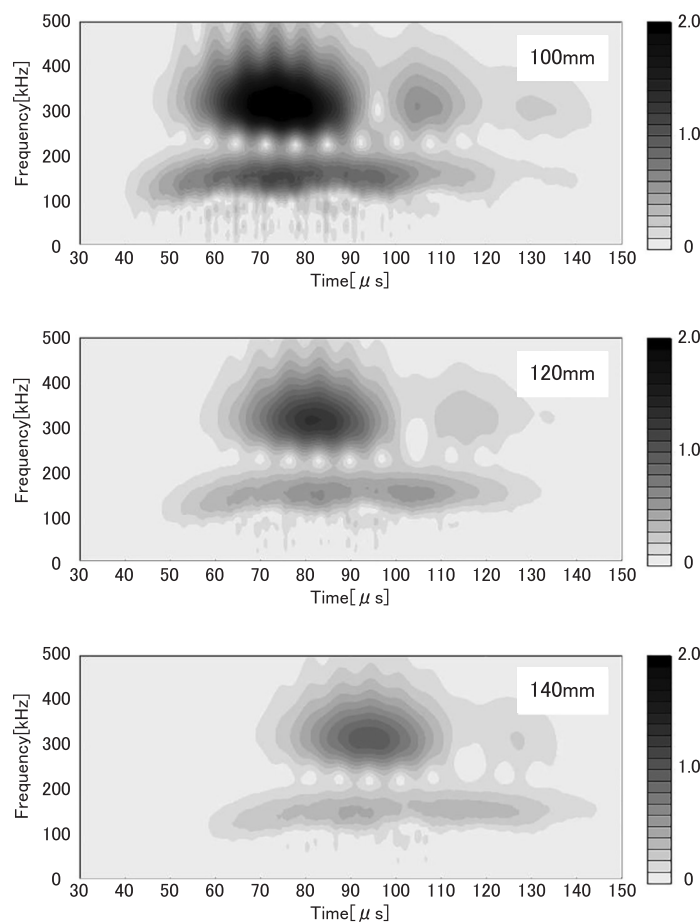

Fig. 8 Example of wavelet transformation of detected waves. Two peaks appeared, which correspond to $\mathrm{S}_{0}$ mode waves in different frequency regions.

板を対象として，タイヤ探触子を用いて Fig. 5 に示すよ うに硬化部から硬化不良部にかけてラム波による検査を 行った。前節と同じく熱可塑性樹脂層側から超音波を送 受信し，入力信号は搬送波周波数 $320 \mathrm{kHz}$ で振幅 100 Vp-p, 5 周期分のバースト波を用いた. 走査距離は完全硬 化部と未硬化部を含む $200 \mathrm{~mm}$ とし，10 mm 間隔で波形 を取り込んだ。また, タイヤ探触子間のラム波伝播距離 を $100 \mathrm{~mm}, 120 \mathrm{~mm}, 140 \mathrm{mmn}$ の 3 パターンに変化させ て伝播距離の変化が測定結果に与える影響を調査した。

Fig. 9(a)，（b）にラム波伝播距離 $100 \mathrm{~mm}$ の場合の硬化 部 (0 mm) と硬化不良部 $(160 \mathrm{~mm})$ それぞれの受信波 形を示す。硬化不良部ではラム波の減衰が大きくなるた め伝播効率が低下し, 硬化部に比べ振幅が大きく低下し ている。測定位置による受信波振幅の変化を示した Fig 10 をみると，いずれの伝播距離においても波形取り込み 位置が $150 \mathrm{~mm}$ を越えたあたりから振幅が大きく低下し ているのがわかる。また，ラム波伝播距離が長くなるに つれて受信波振幅が低下する傾向も確認できた.しかし， 硬化部においても振幅が大きくぼらつく傾向がみられ 


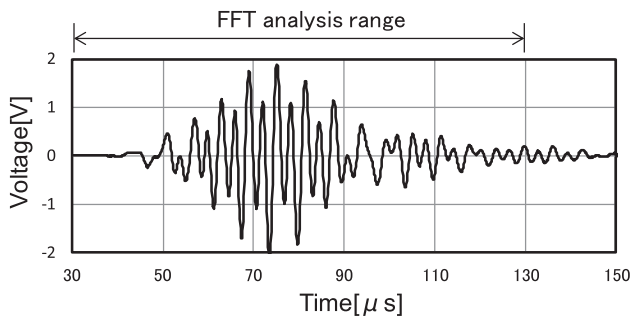

(a) Cured region (with couplant)

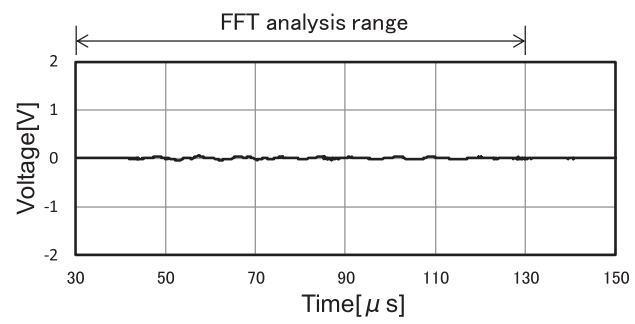

(b) Uncured region (with couplant)

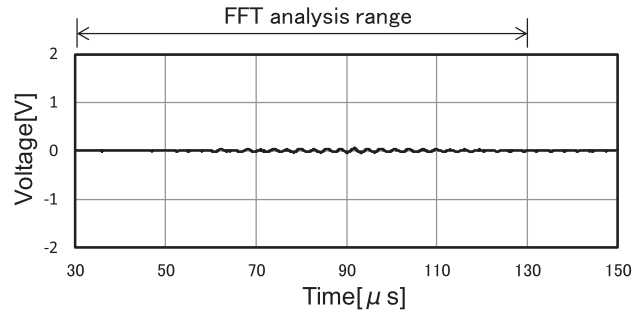

(c) Cured region (without couplant)

Fig. 9 Example of detected waveforms. (propagation distance: $100 \mathrm{~mm}$ )

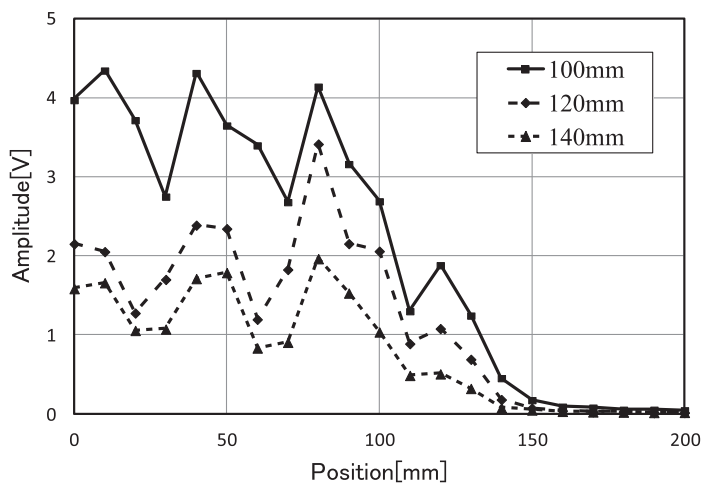

Fig. 10 Variation in amplitude with position for different propagation distances.

る.これは試料の表面状態によりタイヤ探触子と試料の 接触状態が変化しラム波の送受信効率がばらついたこと が原因と考えられる。

Fig. 9 (c) は夕イヤ探触子と試料の界面に接触媒質を

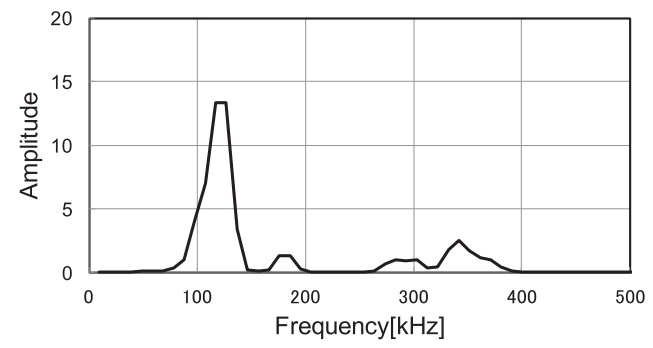

(a) Uncured region (with coupling medium)

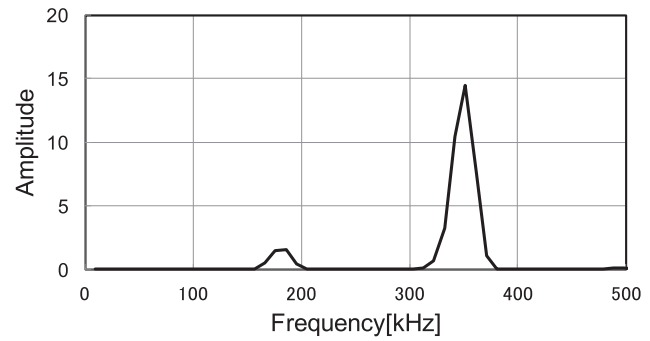

(b) Cured region (without coupling medium)

Fig. 11 Comparison of power spectrums obtained in cured and uncured regions. (propagation distance: $100 \mathrm{~mm}$ )

塗布しなかった場合の受信波形である. 同図はFig. 9 (a)，(b)とは別試料の同等品硬化部に対するデータであ るが, 接触媒質がない場合はラム波の送受信効率が下が るため受信波振幅が大きく低下しており，硬化部におい てもFig. 9(b)で示した硬化不良部での信号強度と同等 の信号しか検出できなかった。下水道更生管のような大 型構造物の検査では夕イヤ探触子を試料表面上で走査し ながらの検査となるため, 接触媒質が適切に塗布できな い状態での検査も想定される。このような場合, 受信波 振幅の低下が硬化不良によるものか夕イヤ探触子の接触 不良によるものかを判別することは困難である. 以上の ことから, 受信波振幅にかわるより高精度の評価指標が 必要と思われる。

\section{$3.4 \mathrm{AU}$ パラメータによる評価}

前節で示したように，受信波に変化をもたらす要因と して試料の硬化不良だけではなくタイヤ探触子と試料の 接触状態が挙げられる. 受信波振幅のみを評価指標とし た場合，Fig. 9 で示したように両者を区別することは困 難であるため, 本研究では受信波の周波数領域での評価 を試みた. 周波数解析に際しては, 波形の第 1 ピーク後方 に現れる $\mathrm{A}_{0}$ モードの影響を排除するため，第 1 ピーク を中心として区間幅 $80 \mu \mathrm{s}$ でハニングウィンドウを適用 した後 FFT 解析を行った. Fig. 11 は Fig. 9(b), (c)の波 


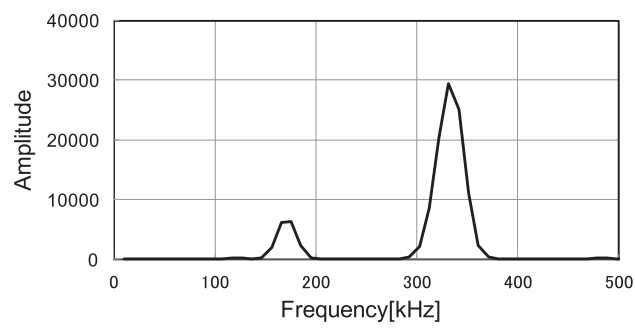

(a) Position: $0 \mathrm{~mm}$ (cure degree is high)

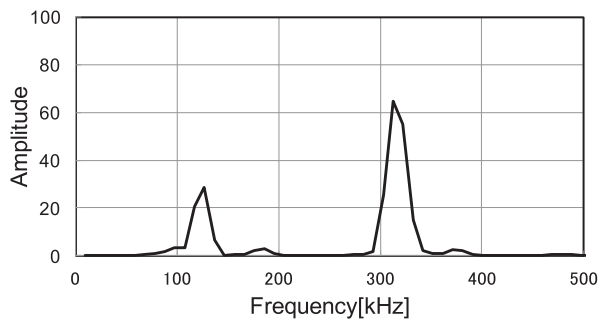

(b) Position: $150 \mathrm{~mm}$ (cure degree is middle)

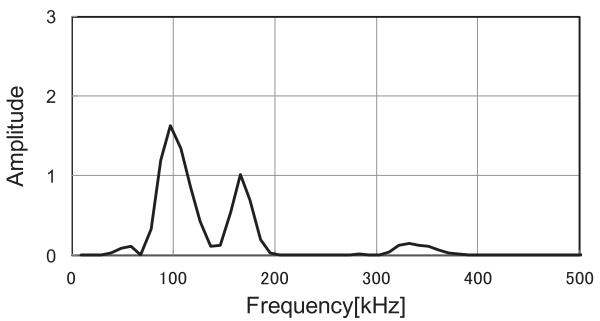

(c) Position: $180 \mathrm{~mm}$ (cure degree is low)

Fig. 12 Comparison of power spectrums at regions of various cure degree. (propagation distance: $100 \mathrm{~mm}$ )

形を図中に示す区間で周波数解析して得たパワースペク トルである，図より明らかなように，硬化部では入力周 波数である $320 \mathrm{kHz}$ 付近の波が相対的に強く検出され ているのに対し，硬化不良部では $130 \mathrm{kHz}$ 付近の比較的 低い周波数成分しか検出されていない. $130 \mathrm{kHz}$ 付近の 成分は探触子の低次の共振周波数付近であり波長が長い ため比較的減衰しにくい. すなわち Fig. 11 は硬化不良 部においてラム波の高周波数成分が選択的に減衰したこ とを示しており，このようなスペクトル線図の変化は硬 化・未硬化の判定指標として使用できる可能性がある.

Fig. 12 は波形取り込み位置が $0 \mathrm{~mm}$ (硬化部)，150 $\mathrm{mm}$ (中間領域), $180 \mathrm{~mm}$ (硬化不良部) の受信波スペル クトルを比較したものであり，いずれも接触媒質を使用 した測定結果である.グラフより, 硬化部である $0 \mathrm{~mm}$ の スペクトル線図においてバースト波で励起した $320 \mathrm{kHz}$ 付近の波が強く検出されていることがわかる.一方で,
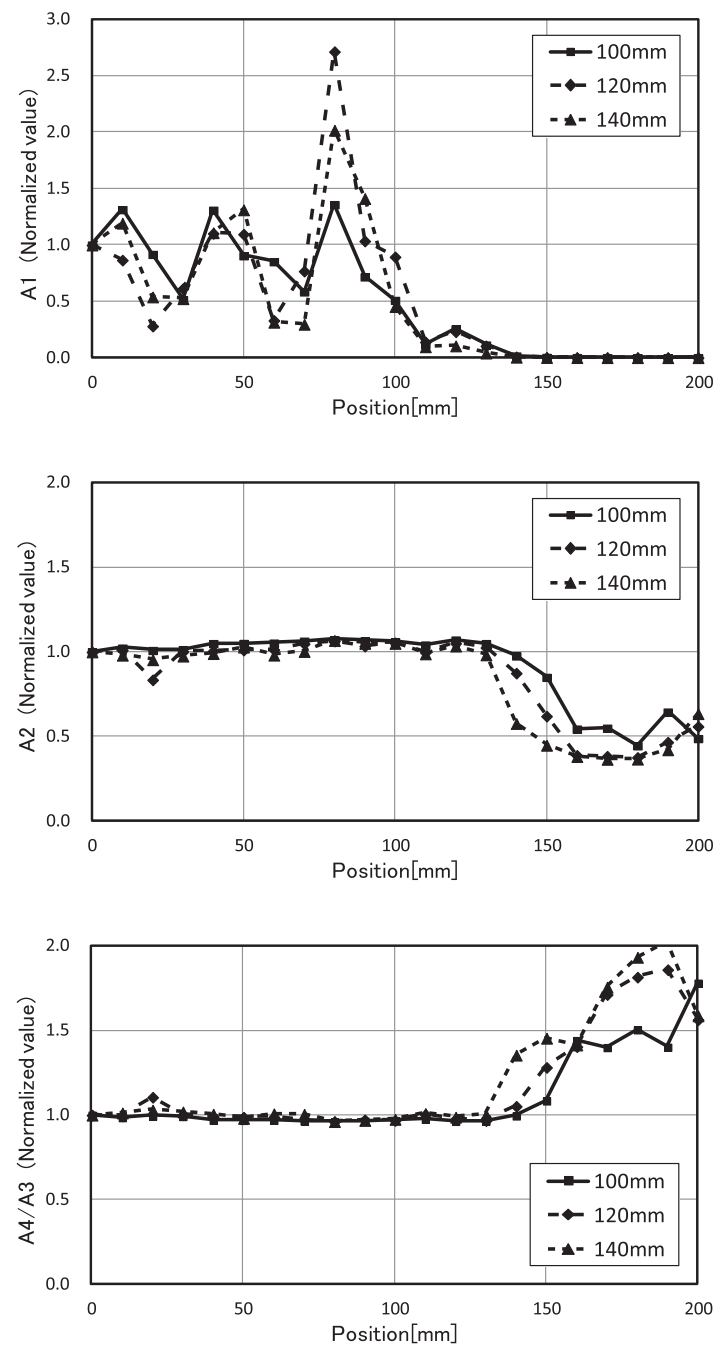

Fig. 13 Variation in AU parameters with position for different propagation distances.

硬化不良部である $180 \mathrm{~mm}$ のスペクトル線図では入力周 波数である $320 \mathrm{kHz}$ 付近の成分は微弱で, $100 \mathrm{kHz}$ 付近 の成分が相対的に強く検出された. また, 硬化部と硬化 不良部の中間領域である $150 \mathrm{~mm}$ では $100 \mathrm{kHz}$ 付近, 320 $\mathrm{kHz}$ 付近の両成分とも比較的強く検出されている.これ らの結果は試料の硬化度が低下するに伴い, 高周波数成 分がより激しく減衰したことを意味している。このよう なスペクトル線図の変化を定量的に評価するためには 2.2 節で述べた $\mathrm{AU}$ パラメータが有効であると考えられる.

Fig. 13 は各測定位置における各種 $\mathrm{AU}$ パラメータの 変化を示しており, 波形取り込み位置 $0 \mathrm{~mm}$ での值を基 準として縦軸を正規化したものである。本研究では, 波 
の総エネルギに相当する $A 1$ パラメータ，スペクトル線 罒の図心に相当する $A 2$ パラメータ，スペクトル線図の ねじれに相当する $A 4 / A 3$ パラメータに注目した. $A 1$ パ ラメータは受信波振幅と同様の変化傾向を示し硬化部で のばらつきが大きい.その他のパラメータでは硬化して いる左側領域に拈いて変化が少なく, 未硬化の右側領域 において変化がみられる. $A 2$ パラメータの場合, 硬化不 良部で低下する傾向がみられるが，これはFig. 12 に示 したように高周波数成分の減衰によってスペクトル線図 の図心が低周波数側に移動したことを反映している。ま た，受信波の主要周波数成分 $(320 \mathrm{kHz}$ 付近）の減衰を 反映して，時間波形の 0 レベル通過周波数を表す $A 3$ パ ラメータは低下し, 受信波の最高周波数に相当する $A 4$ パラメータは比較的変化が小さいため, スペクトル線図 のねじれを表わす $A 4 / A 3$ パラメータは硬化不良部であ るグラフ右側で増加している. $A 2, A 4 / A 3$ パラメータの グラフにおいて測定位置 $180 \mathrm{~mm}$ 以降でデータのばらつ きが大きくなる傾向がみられるが，この領域では試料の 硬化度が極端に低く $A 1$ パラメータが示すように受信波 が著しく減衰したため, ノイズの影響を比較的強く受け たと考えられる.ここで, 伝播距離による検出精度の差 を比較すると, ラム波伝播距離が長い $140 \mathrm{~mm}$ の場合が 最も変化が大きく感度が高いことがわかる. 本実験で使 用したのは硬化不良部が一次元的に分布した試料であ り, 各測定位置でラム波伝播経路の硬化状態はほぼ一様 とみなせる.よって, 伝播距離を伸ばすことでラム波が 硬化不良部の影響をより強く受けるようになり, $\mathrm{AU}$ パ ラメータの変化が大きくなったものと解釈できる. しか し，ラム波伝播距離を伸ばすことで受信波強度が弱まり 信号の SN 比が低下するため, 被検査材料に則して伝播 距離を適切に設定する必要がある.

次に, 各種 $\mathrm{AU}$ パラメータの硬化不良部検出感度につ いてみると, $A 1$ パラメータが $110 \mathrm{~mm}$ あたりから急激 に低下しているのに対し, $A 2$ および $A 4 / A 3$ パラメータ は $130 \mathrm{~mm}$ あたりから大きく変化しており, 硬化不良に 対しては $A 1$ パラメータが最も感度が高い. しかし, 前節 で示したように，受信波振幅と相関のある $A 1$ パラメー 夕は夕イヤ探触子と試料の接触状態の影響を強く受ける ため, このデータのみから硬化不良を判定することはで きない. 複数の AU パラメータを複合的に評価すること で検査精度を高められると考えられる。

\section{4. ラム波測定結果と力学特性の比較}

前章までに示したラム波測定結果と実際の材料強度,
剛性との間にどの程度の相関があるかを調べるために, JIS K 7171 に基づき三点曲げ試験を行った.サンプルは Fig. 5 の超音波伝播方向に平行に幅 $20 \mathrm{~mm}$ の短冊状で 切り出し, 完全硬化側 (No.1) 加 未硬化側 (No. 10) の 10 本を測定した. 試験条件は負荷速度 $2 \mathrm{~mm} / \mathrm{min}$, サ ポートスパンは $60 \mathrm{~mm}$ とした. Fig. 14 に代表的なサン プリング位置での荷重-たわみ線図を示す。いずれのサ ンプルにおいても初期の線形領域のあとに非線形領域が 現れ, 荷重ピーク以降も荷重負担能力を完全には失わず, ある程度の荷重負担能力を保持している. 本研究で用い た供試材は Fig. 5 で示したような積層構造を有してお り, 表面材である熱可塑性樹脂, PET 繊維製織物は非線 形特性を有している. 荷重ピーク以前にみられる非線形 現象は主に表面材の非線形特性に起因している。硬化不 良部は中間層である SMC 層のみで発生しており，サン プル採取位置が硬化不良部側に近付くにつれて傾きが低 下し，最大荷重も低下する傾向がみられる．荷重ピーク

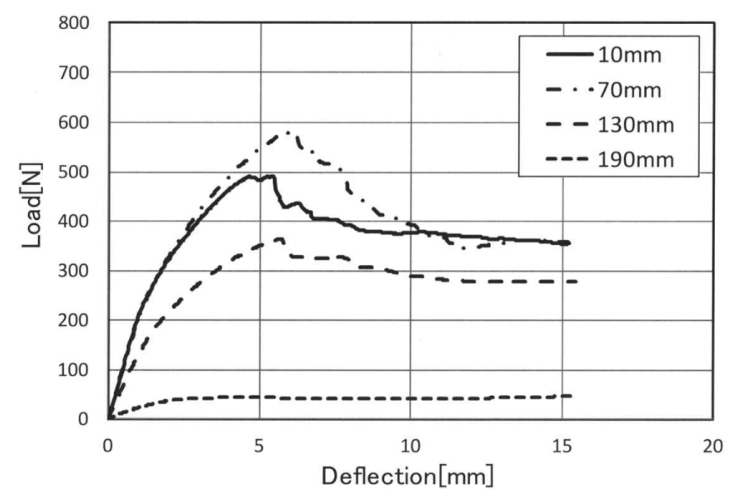

Fig. 14 Comparison of load-deflection curves between samples with different degree of cure.

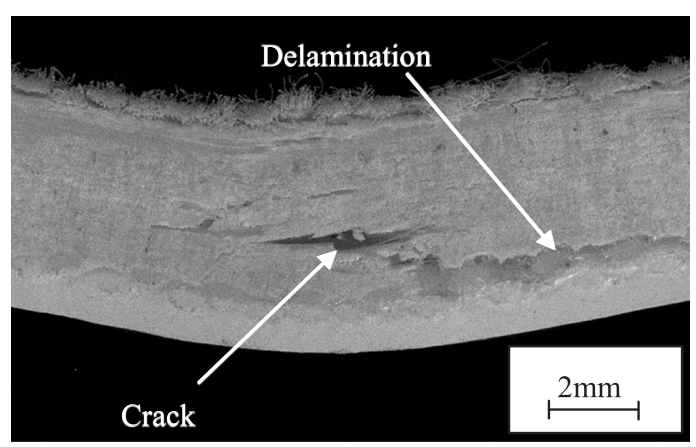

Fig. 15 Photograph of specimen cross-section after 3 points bending test. 

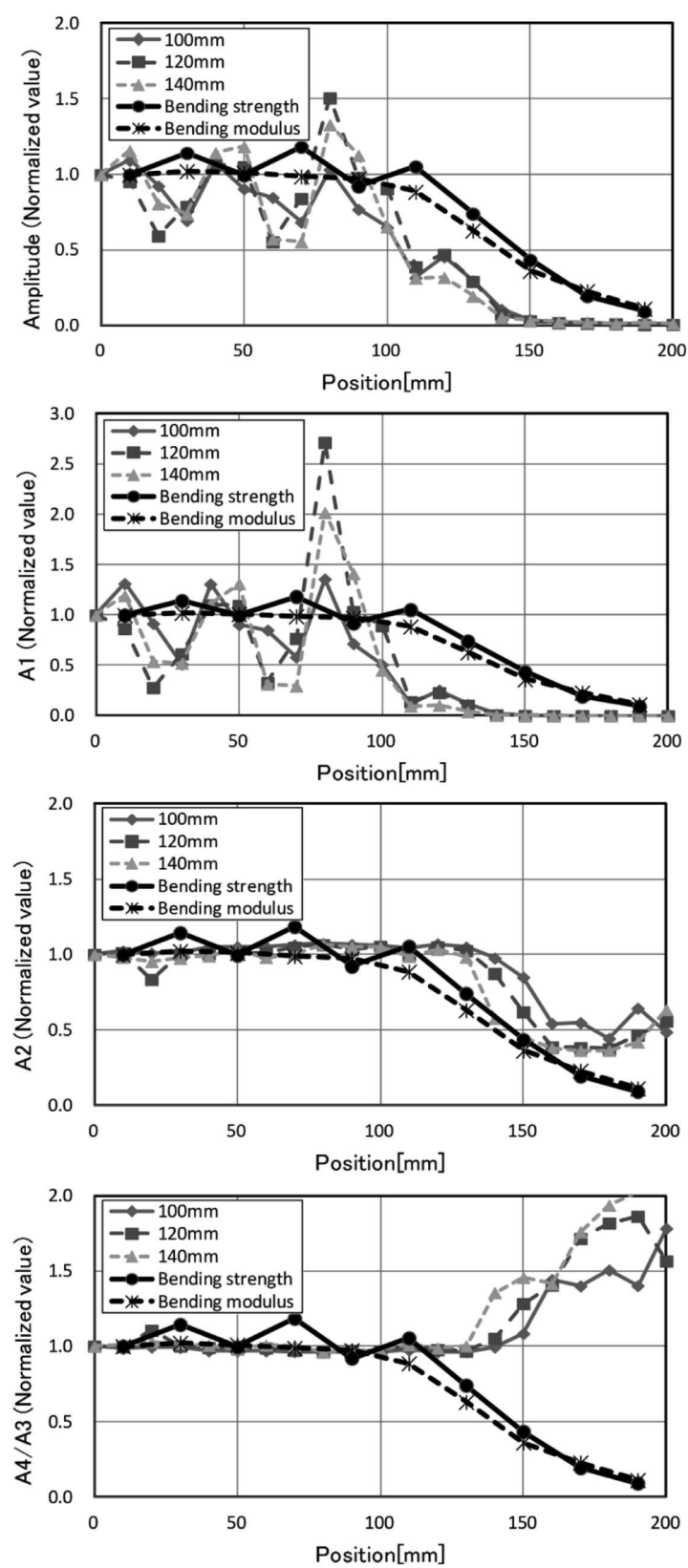

Fig. 16 Comparison between ultrasonic testing and mechanical properties.

付近では Fig. 15 に示すような表面材のはく離が観察さ れ，その後はく離を起点とした SMC 層の破壊が観察さ れた。荷重ピーク以降では, 表面材である熱可塑性樹脂, 有機繊維製織物が主に荷重を負担しているため，一定の 荷重負担能力を保持できたと考えられる。
Fig. 16 は積層材試料を均質材とみなして Fig. 14 から 曲げ強度・弾性率を算出し, 受信波振幅㧍よび各種 $\mathrm{AU}$ パラメータと比較したグラフであり, 位置 $0 \mathrm{~mm}$ での值 を基準として縦軸を正規化したものである。曲げ強度・ 曲げ弾性率は位置 $110 \mathrm{~mm}$ 付近から低下し始めており, この付近から SMC 層の硬化度が低下していると予想さ れる。一方，受信波強度・ $A 1$ パラメー夕も同じ付近から 低下寸る傾向にあるが, $A 2, A 4 / A 3$ パラメー夕に変化が でる位置は力学特性低下位置よりも若干遅い。超音波伝 播特性は材料の弾性率, 粘弾性特性, 内部欠陥などに依 存しているため, 一般的に材料の巨視的弾性率との相関 はあるが, 強度との直接的な相関はない. しかし, 今回 の試料では樹脂硬化度が主な変化要因であり, 樹脂硬化 度の増加に伴い曲げ強度・曲げ弾性率はともに増加傾向 を示すことから, 結果として超音波測定結果と曲げ強度 の間にもある程度の相関がみられた。下水道更生管にお いては強度保証が重要となることから, 本研究で示した 評価手法により間接的に強度評価ができることは実用上 有益と思われる。

5. 結言

本研究では超音波による下水管更生用 GFRP 成形板 の硬化不良部検出の時間短縮を目的として，タイヤ探触 子により発生させたラム波を用いた検查法について検討 した。評価パラメータとして受信波形の振幅に加え, 周 波数領域での変化を定量化するために $\mathrm{AU}$ パラメー夕 を導入し，その有効性を検証した。 以下に得られた結論 を示す.

（1）受信波の振幅強度および受信波の総エネルギを表 す $A 1$ パラメータを用いることで硬化不良部の検出が可 能であるが，被検查材に対するラム波の入射効率の影響 を受けるため硬化部においてもデータの摇らぎが生じや すい.

（2）スペクトル線図の図心に相当する $A 2$ パラメー 夕，およびスペクトル線図のねじれに相当する $A 4 / A 3$ パラメータは, スペクトル線図の幾何形状に依存してお り，硬化不良部での高周波数成分の選択的隇衰を反映し て硬化不良部で大きく変化する。 また，探触子の接触状 態の影響を受けにくく，硬化部でのデータの摇らぎが少 ない.

（3）ラム波測定結果と曲げ試験結果を比較した結果， 強度・弾性率が低下し始める位置と受信波振幅㧍よび $\mathrm{AU}$ パラメータが変化し始める位置は概ね対応したが, $A 2, A 4 / A 3$ パラメー夕に変化がでるのは力学特性低下 
位置よりも若干遅いことから受信波振幅, $A 1$ パラメー 夕に比べて硬化不良に対する感度がやや低い.

以上の結果より, 160〜 $320 \mathrm{kHz}$ 程度の広帯域のラム波 を試料に励起できる場合には, AUパラメータによる硬 化不良検出が可能であることがわかった. $5 \mathrm{~mm}$ を超え る板厚になると $\mathrm{S}_{0}$ モードと $\mathrm{A}_{0}$ モードの位相速度が近 づき伝播距離 $100 \mathrm{~mm}$ 程度では時間領域におけるモード 分離が困難になるため, 伝播距離を長くする必要がある. しかし, 伝播距離が長くなると受信波強度が弱まり信号 の SN 比が低下するため設定できる伝播距離には限界が ある。本手法の厚板への適用に際しては, 波の干渉の影 響を別途評価する必要がある。また，本研究では，表面 材を有する板厚方向に非対称な積層板を均質材とみなし て解析したため理論的な厳密性に欠ける部分もあるが, 本手法は実用的には十分利用可能であると思われる.

\section{参 考 文 献}

1）松木 靖: 月刊下水道, 35, 61（2012）, 25-28.

2) J.G. Kim \& D.G. Lee : Compos. Struct., 57, 1-4 (2002), 91-99.

3) J. Leng \& A. Asundi : Sensor and Actuators A,
103, 3 (2003), 330-340.

4) D.D. Shepard \& K.R. Smith : Sensor Review, 19, 3 (1999), 187-191.

5）山崎友裕, 西野博満, 片山大希：日本機械学会論文 集 A 編, 76, 62 (2010), 145-150.

6) N. Guo \& P. Cawley: J. Acoust. Soc. Am., 94 (1993), 2240-2246.

7) K.S. Tan, N. Guo \& B.S. Wong: Compos. Sci. Technol., 53 (1995), 77-84.

8) D. Royer \& E. Dieulesaint: Elastic Waves in Solids I: Free and Guided Propagation, Springer (2000).

9）武藤伸之：非破壞検査， 52,1 (2003), 20-25.

10) M.T. Kiernan \& J.C. Duke Jr. : Materials Evaluation, 46 (1988), 1105-1113.

11) M.T. Kiernan \& J.C. Duke Jr. : Materials Evaluation, 46 (1988), 1344-1352.

12) O.Y. Kwon \& S.H. Le : NDT\&E International, 32 (1999), 153-160.

13）和田明浩, 元木信弥, 山崎友裕：日本機械学会論文 集 A 編，78, 790 (2012), 879-889.

14) D.E. Newland: An Introduction to Random Vibrations and Spectral Analysis (1983).

15）西野秀郎：日本非破壊検査協会誌, 62, 1 (2013), 2934 . 